відношенню до обвинуваченого. Адже потерпілий може не володіти ні спеціальними знаннями (освітою), ні коштами для запрошення представника (захисника), що не дасть йому можливості у повній мірі реалізувати своє право на підтримання обвинувачення. Такі зміни створять умови для реалізації на основі засади змагальності функції обвинувачення всіма суб'єктами з боку обвинувачення.

Література:

1. Конституція України: Закон від 28.06.1996 № 254к/96-ВР // Відомості Верховної Ради України, 1996, № 30, ст.141.

2. Кримінальний процесуальний кодекс України від 13.04.2012 № 4651-VI // Відомості Верховної Ради України, 2013, № 9-10, № 11-12, № 13, ст.88.

3. Учасники кримінального провадження, що здійснюють функцію обвинувачення в кримінальному провадженні України і Польщі. Садова Т.В. // Прикарпатський юридичний вісник. - Випуск 2(11), 2016. С. 104-108.

4. Рогатюк I.B. Обвинувачення у кримінальному процесі України: Монографія - К.: Атіка, 2007.- 160 с.

Науковий керівник: д.ю.н., проф. Смоков С.М.

Стаття відправлена: 08.04.2017 p.

(C) Кузьменко В.М., Піменова А.Ю.

ЦИТ: ua117-057

DOI: 10.21893/2415-7538.2016-05-1-057

УДК 327.5:001.891.3

\title{
ТЕОРІЯ ПОЛІТИЧНИХ КОНФЛІКТІВ
}

Іскра К.O.,

\section{THEORY OF POLITICAL CONFLICTS}

Iskra K.O.

Анотація. У статті окреслюються структура політичних конфліктів, технології $i$ практика управління ними, пояснюється поняття суб'єкта $i$ об'єкта політичного конфлікту, перераховані функиії політичного конфлікту, а також наведено інформачію про розробників теорії конфлікту.

Ключові слова: політика, конфлікт, боротьба, Карл Маркс, Алексіс де Толквіль, консенсус, функиії, суспільство, типологія конфліктів..

Abstract. The article determines the structure of political conflicts, technology, and practice management, explains the concept of subject and object of a political conflict. The article provides information about functions of the political conflict, including information about the developers of the theory of it.

Key words: politics, conflict, struggle, Karl Marx, Alexis de Tocqueville, consensus, function, society, typology of conflicts.

Актуальність дослідження теорії політичних конфліктів полягає в тому, що вивчення конфліктів $є$ завжди актуальним, так як 3 кожним днем ми спостерігаємо тенденцію до наростання конфліктів, їх загострення особливо в політичному плані. До того ж дослідження конфліктів $є$ одним із передових завдань політології. 
Новизна роботи полягає в тому, що кожний автор має свою власну думку на ту чи іншу ситуацію (питання), і в даній статті наведено власне думку автора щодо теорії політичного конфлікту.

Поняття «політичний конфлікт» передбачає протистояння різних соціально-політичних сил, протилежних сторін в їх прагненні реалізувати свої інтереси і цілі, пов'язані, насамперед, із боротьбою за здобуття влади, іiі перерозподіл, використання політичної влади, за зміну свого політичного статусу, а також з політичними перспективами подальшого розвитку [1].

Саме політика $є$ тією основою, на якій найчастіше виникають конфлікти, $\mathrm{i}$ хоча, 3 одного боку, вона й передбачає вирішення спірних питань i попередження виникнення онних, з іншого ж - політика нерозривно зв'язана 3 боротьбою за владу, що $є$ плацдармом для конфліктів, тобто засобом їх провокування.

Як і будь-які інші види конфліктів, політичний не виникає безпричинно, зазвичай передумовами можуть бути: невідповідність між тим, на що сподівалися i тим, що врешті отримали, тобто реальністю; як і в решті конфліктів, в основі завжди лежить нерівність людей; розбіжності між суспільними та індивідуальними цінностями; протилежні типи лідерства; неправдива інформація, яка спотворює дійсний стан ситуації; і звісно, в будьякій людині закладене прагнення завоювати і утримати владу [2].

Вперше теорію політичного конфлікту досліджували Карл Маркс та Алексіс де Толквіль, саме їх і вважають основоположниками. Перший - вважав, що причиною виникнення політичного конфлікту завжди виступає нерівність між класами, на які умовно діляться соціально-економічні структури [5]. Саме дана нерівність є основою боротьби. А.Толквіль - висунув ідею про те, що демократія включає баланс між силами конфлікту й консенсусу, спираючись на політику соціального партнерства.

Суб'єктами політичного конфлікту виступають окремі держави, партії, організації та рухи, тобто «одиниці», що приймають участь в політичному житті. Іншим елементом конфлікту є об'єкт (предмет). Зазвичай ним виступає інтерес, визначений суб'єктами конфлікту, виражений в їх обгрунтованому або помилковому праві на щось. Саме об'єкт і суб'єкт політичного конфлікту являють одну із ланок його структури [3].

Також, політичний конфлікт має свої функції, до них належать сигнальна, інформаційна, диференційна, інтеграційна та динамічна. Перша 3 них характеризує конфлікт як певний показник стану суспільства. Завжди, де виникає конфлікт, надалі йдуть серйозні зміни. Інформаційна проявляється в тому, що будь-які зміни, повороти конфліктної ситуації несуть в собі певну інформацію, і вивчення цієї інформації - $є$ одним із найважливішим засобом пізнання тих проблем і процесів, що виникають у суспільстві. Диференційна функція полягає в тому, що під впливом конфлікту відбувається процес соціальної диференціації, що призводить до руйнування старих структур, а також змін співвідношення їх елементів. Виділяють також інтеграційну функцію, чия суть полягає в тому, що зазвичай в ситуації протистояння із іншими групами, всередині самої групи відбувається об'єднання. I остання із 
функцій, і напевно найважливіша, полягає в тому, що будь-який конфлікт сприяє розвитку, спонукає рухатися вперед.

Доречно також розглянути типологію політичних конфліктів. Загалом політичні конфлікти можна розділяти за певними критеріями, наприклад:

з точки зору області їх прояву. Так, виділяють внутрішньо - i зовнішньополітичні конфлікти.

за характером їх нормативної регуляції, тобто за тим, здатні чи не здатні люди підкорюватися обраним правилам політичної гри.

за характеристиками, що відображають рівень залучення людей до вирішення суперечностей, конфлікту, а також їх вплив та значення на динаміку розвитку політичного процесу [4].

за часовими рамками, тобто тривалістю конфлікту. Виділяють довготривалі та короткочасні політичні конфлікти.

за характером вияву (прояву) конфлікту: відкриті (явні), латентні

$>$ у співвідношенні з організацією режиму правління. Так, розрізняють вертикальні конфлікти (передбачають взаємовідносини між суб'єктами, що належать до різних рівнів влади) та горизонтальні (взаємовідносини між суб'єктами однакового соціального становища, наприклад, між правлячими партіями).

Процес самого політичного конфлікту можна розділити на 4 етапи, такі як: перед конфліктом, процес конфлікту, розв'язання конфлікту та його логічне завершення. В свою чергу, кожен з етапів включає в себе кілька фаз.

Перша стадія $є$ латентною (прихованою) і включає дві фази. Перша фаза характеризується накопиченням незадоволення через глибокі розбіжності інтересів і цінностей суб'єктів конфліктної ситуації. Друга фаза представляє собою інцидент, ситуацію, яка є стартом для подальшого розвитку політичного конфлікту, початку боротьби [4].

Конфліктну стадію можна охарактеризувати гострим протистоянням між конфліктуючими сторонами, зіставлення сил цих сторін, як фізичних так $\mathrm{i}$ інформаційних та інших, також відбувається оцінювання шансів кожного.

Стадія розв'язання конфлікту передбачає процес зміни взаємовідносин між ворогуючими сторонами, тобто відбуваються зміни в свідомості, що в свою чергу провокує опонентів по-новому оцінити ситуацію, що склалася, і замість протистояння поступово перейти до співпраці.

Остання стадія являється логічним завершенням, тобто подолання всіх конфліктних суперечностей і повне припинення боротьби.

Однак, щоб досягти позитивного результату, необхідно вміти регулювати політичний конфлікт. На сьогодні вже виділено і затверджено кілька конкретних методів вирішення конфліктів [5].

Перший із них - це метод уникнення конфлікту. Якщо $є$ шанс уникнути проблеми, то ним гріх не скористуватися, однак слід пам'ятати, що вогню без іскри не буває, а значить протиріччя, на основі якого виник конфлікт, нікуди не ділося.

Наступний - це заперечення конфлікту, такий спосіб ставлення до конфлікту, при якому він починає змінюватися і переміщається в іншу 
площину.

Третій метод - конфронтації, однак він має ряд недоліків, так як, наприклад, може призвести до краху політичного режиму.

Четвертий метод найчастіше використовують в практиці політичної боротьби, він проявляється в тому, що певна сторона відкладає конфлікт, тобто здається. Однак, після здачі своїх позицій, нерідко ставалося так, що дана сторона старалася повернути втрачене в минулому.

Останній метод полягає в примиренні сторін на основі зближення їх інтересів та позицій, зазвичай за допомогою посередника, яким можуть виступати погоджувальні комісії або окремі діячі та країни.

Висновки. Теорія політичних конфліктів $\epsilon$ однією 3 центральних в сучасній політології. Їй привчено щонайменше $50 \%$ усіх досліджень, що пояснюється тим фактом, що конфлікт і політика нерозривно зв'язані. Конфлікт несе в собі як загрозу стабільності, так і $є$ тим привідом, що сприяє розвитку, удосконаленню.

Використані джерела:

1. Політологія: підручник / Ред. О. В. Бабкіна, В. П. Горбатенко. - К. : ВЦ "Академія", 2003. - 182 с. - (Альма-матер).

2. Поняття та причини міжнародного конфлікту [Електронний ресурс]. http://studall.org/all3-1461.html

3. Розенфельд Ю.Н. Специфика политических конфликтов [Електронний pecypc]. -http://www.rusnauka.com/ONG/Politologia/2.doc.htm

4. Теоретичне осмислення політичних конфліктів [Електронний ресурс]. http://storykol.com/teoretichne-osmislennya-politichnih-konfliktiv/

5. Политический конфликт [Електронний ресурс]. http://bibliofond.ru/view.aspx?id=719907

Науковий керівник - кандидат історичних наук, дочент кафедри історії $i$

політологї Начіонального університету біоресурсів і природокористування України Сєкунова Ю.В..

ЦИТ: иа117-130

DOI: 10.21893/2415-7538.2016-05-1-130

УДК 316.343.3

Мокшин В.К., Шипелик О.В. ДИСКУССИОННЫЕ ПРОБЛЕМЫ ИССЛЕДОВАНИЯ СОВРЕМЕННОГО ЭТАПА ПОЛИТИЧЕСКОГО ПРОЦЕССА В ВОСТОЧНОЕВРОПЕЙСКИХ CTPAHAX

Северныий (Арктический) Федеральный университет им. М.В. Ломоносова, Архангельск, Набережная Северной Двиньл 17, 163002

Южный Федеральный университет, Ростов-на-Дону, ул. Большая Садовая, 105/42, 344006

Mokshin V.K., Shipelik O.V. DISCUSSION PROBLEMS OF RESEARCH THE MODERN STAGE OF THE POLITICAL PROCESS IN THE EASTERN EUROPEAN COUNTRIES 